\title{
Investigation of the Structural Deformation Behaviour of the Subsoiler and Paraplow Tines by Means of Finitie Element Method
}

\author{
Kemal Çağatay Selvi* \\ Department of Agricultural Machinery and Technologies Engineering, Faculty of Agriculture, Ondokuz Mayls University, \\ 55200 Atakum/Samsun, Turkey
}

\section{A R T I C L E IN F O}

\section{Research Articles}

Received 31 July 2017

Accepted 19 October 2017

Keywords:

Subsoiler

Paraplow

Static analysis

Finite element method

Design

\begin{abstract}
A B S T R A C T
In this study, static stress-deformation analyzes (in terms of material strengths) were presented comparatively through a FEM-based simulation of the subsoiler and paraplow legs designed in a three-dimensional CAD environment. In general, both soil tillage implements with high energy requirements are being used to remove the soil compaction problem on agricultural land. The operating conditions of the implements were simulated using a FEM-based simulation program (Ansys-16). The results of static analysis obtained from the Finite Element Method (FEM) were evaluated on some different materials used in the shank design of both implements and the results were given comparatively. According to the analysis results, the maximum equivalent stress was in paraplow shank foot $122 \mathrm{MPa}$ which is used C-60 material and the maximum vertical displacement is $0,00014 \mathrm{~mm}$ in the position of shank foot of subsoiler
\end{abstract}

$\frac{\text { "Corresponding Author: }}{\text { E-mail: kcselvi@omu.edu.tr }}$

Türk Tarım - Gıda Bilim ve Teknoloji Dergisi, 5(12): 1482-1487, 2017

\section{Dipkazan ve Şekilsiz Pulluk (Paraplow) Ayaklarının Yapısal Deformasyon Davranışının Sonlu Elemanlar Yöntemi İle İncelenmesi}

\section{A K A L E B İ L G İ S İ}

\section{AraştırmaMmakalesi}

Geliş 31 Temmuz 2017

Kabul 19 Ekim 2017

\section{Anahtar Kelimeler:}

Dipkazan

Şekilsiz pulluk

Statik analiz

Sonlu elemanlar yöntemi

Tasarım

\section{Ö Z E T}

Bu çalışmada, üç boyutlu bir CAD ortamında tasarımı gerçekleştirilmiş dipkazan ve şekilsiz pulluk ayaklarının, FEM temelli bir simülasyon aracılığıyla statik gerilmedeformasyon analizleri (özellikle mekaniksel dayanımlar açısından) karşılaştırmalı olarak verilmeye çalışılmıştır. Genel olarak, yüksek enerji gereksinimi olan her iki toprak işleme aleti de tarımsal üretim yapılan topraklardaki sıkışma probleminin ortadan kaldırılması amacıyla kullanılmaktadır. Toprak işleme aletlerinin çalışma koşulları, FEM tabanlı bir simülasyon programı (Ansys-16) kullanılarak oluşturulmuştur. Elde edilen statik analiz sonuçları, her iki aletin ayak tasarımında kullanılan bazı farklı malzemeler üzerinden değerlendirilmiş ve sonuçlar karşılaştırmalı olarak verilmeye çalışılmıştır. Analiz sonuçlarına göre; maksimum eşdeğer gerilme $122 \mathrm{MPa}$ ile C-60 malzemeden tasarlanmış paraplow ayağında ve maksimum düşey yerdeğiştirme ise $0.00014 \mathrm{~mm}$ ile dipkazan ayağında gerçekleşmiştir.

\author{
"Sorumlu Yazar: \\ E-mail: kcselvi@omu.edu.tr
}




\section{Introduction}

With increasing technological development, the processing capacities of machines and implements used in agricultural production have been increased. The increase in the weights of these machines and implements, especially when working in extreme moisture conditions, can have some negative consequences that restrict production (Topakc1 et al., 2010). One of the negative effects of the force applied to the soil as a result of this weight increase is the soil compaction. Soil compaction is basically the reduction in volume of a given mass of soil (Pınar, 2008). It is commonly defined as an increase soil bulk density; closing packing of soil particles, and reduced pore size, especially the proportion of large pores (Canillas and Salokhe, 2002 Hassan, 2007, Çelik and Raper, 2012 and Ahmadi, 2016). In compacted soils, plant root length is reduced and the root system develops superficially (Nevens and Reheul, 2003). Furthermore, soil compaction reduces water uptake and decreases infiltration and storage of water in soil (Ghosh et al., 2006).

Mainly, there are few different compaction types such as soil crust, surface compaction, plough pan (hard pan) and deep soil compaction. The plough pan which is one of these, frequently referred to as a pan, is usually relatively strong and more compact (Spoor et al., 2003).

One useful method to avoid negative effects of plowpan in agricultural fields is deep tillage using a subsoiler (Topakc1 et al., 2010) which is a tillage tool that can work up to depths of 250-600 mm under the surface (Çelik and Raper, 2012). Subsoiling equipment takes a variety of forms, with differences in shape and arrangement on a tool frame. The shape and size of a subsoiler has important effects on soil disruption and draft requirement (Çelik and Raper, 2016). To rehabilitate compacted fields, farmers commonly use subsoilers to break and shatter compacted layers (Ahmadi, 2016). There are a number of different subsoilers available in agriculturel market for loosening soil. Alternatively subsoilers can have a bent-leg (Paraplow) design (Figure 1). These subsoilers have a reduced draft requirement and less surface disruption compared with conventional (Smith and Williford, 1988) and straight leg subsoiler (Raper, 2005). The proportion of soil that is loosened is also greater with this type of subsoiler (Raper, 2007).

Computer integrated design software helps in development of complete system design processes, especially the use of three dimensional (3D) solid modelling and finite element analysis (FEA) applications (Topakc1 et al., 2010). Also, such techniques can be used to obtain information about the failure zone, field of stress, soil deformation, acting forces, etc. for any condition of soil (Armin et al., 2014). With the development of finite element technology, the finite element method has been used as an effective method on studying tillage implement (Ma et al., 2016).

The present study focused on the comparison of structural analysis between subsoiler and paraplow shank using FEM. This comparison was made on 2 different materials used for both shanks.

\section{The Establishment of The Shanks}

In both tool designs, the tools are designed to have a single shank. The subsoiler and paraplow consists of three parts: the shank hand, the shank and the foot of shank. The shank hand is used to fix the subsoiler on the rack. Working depth of shanks was selected as $400 \mathrm{~mm}$. The dimensions of shanks (Figure 2) and related parameters and values of the shanks designed for this study are given in Table 1.

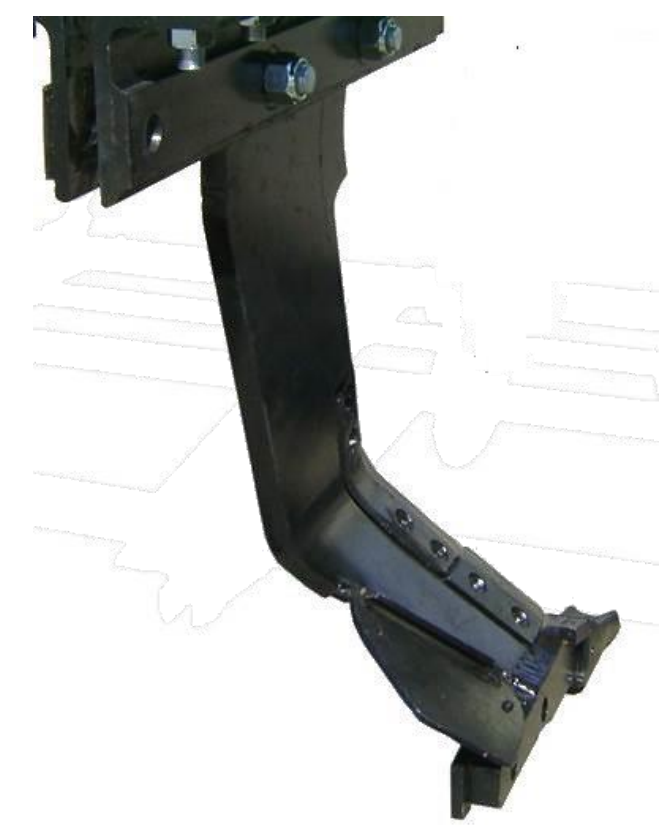

Figure 1 General view of paraplow

\section{The Boundary Conditions and The Load}

At the determination of thedraft force applied to the tines, the data obtained from the field study performed by the Topakc1 et all. 2010. were used. According to this study, the soil structure comprised of sand (15\%), clay $(30 \%)$ and silt $(55 \%)$. Average moisture content of the soil was $4.5 \%$ (d.b.) for dry condition. The maximum draft force value was determined as $32.01 \mathrm{kN}$. In the comparison of static analysis results of the feet, this value was used in terms of the fact that the applied force value is true. "Fixed support" method was used to fix two surfaces which contact with frame and use the "Frictionless support" method to fix locating holes on the shanks. The load using "Force" method is applied to shanks. A load of $30000 \mathrm{~N}$ was applied in the $\mathrm{z}$ direction for subsoiler and y direction for paraplow to the surface of the tools in the $400 \mathrm{~mm}$ loosening depth to be operated under the soil, as is shown in Figure 3.

\section{Finite Element Analysis of Subsoiler and Paraplow}

\section{Material Properties}

Based on the geometrical configuration of the designed shanks two different types of material were selected. When these materials were selected, it was tried to take into consideration the facilities of the materials in the market. Material properties used in the analysis are presented in Table 2. 
Table 1 Constant values considered as input parameters for the model developed in the present study

\begin{tabular}{l|lcc}
\hline \multicolumn{2}{c|}{$\begin{array}{c}\text { Parameter symbol } \\
\text { Parameters }\end{array}$} & \multicolumn{1}{c}{ Definition } & Value \\
\cline { 2 - 4 } $\mathrm{W}$ & Foot width of the subsoiler & $70 \mathrm{~mm}$ & Paraplow \\
$\mathrm{b}$ & Thickness of the subsoiler shank & $50 \mathrm{~mm}$ \\
$\mathrm{t}$ & Width of the subsoiler shank & $30 \mathrm{~mm}$ & $30 \mathrm{~mm}$ \\
$\mathrm{~N}$ & Number of subsoiler shanks & $150 \mathrm{~mm}$ & $250 \mathrm{~mm}$ \\
$\mathrm{~d}$ & Angle of toe & 1 & 1 \\
$\mathrm{l}$ & Total lenght of the subsoiler & $775 \mathrm{~mm}$ & 30 \\
$\mathrm{Z}$ & Height of subsoiler foot & $45 \mathrm{~mm}$ & $730 \mathrm{~mm}$ \\
$\mathrm{f}$ & Lenght of subsoiler foot & $320 \mathrm{~mm}$ & $78 \mathrm{~mm}$ \\
$\mathrm{~h}$ & Working depth & $400 \mathrm{~mm}$ & $390 \mathrm{~mm}$ \\
\hline
\end{tabular}

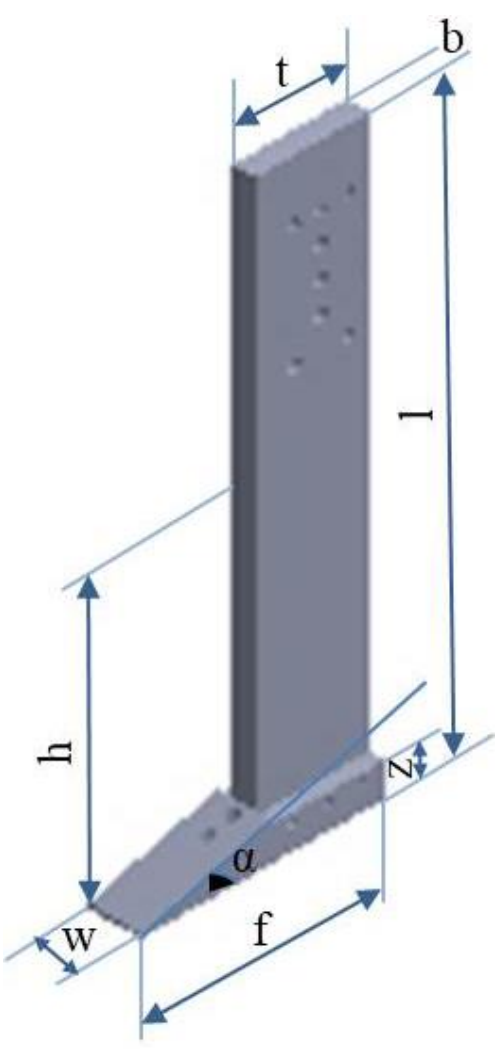

(a)

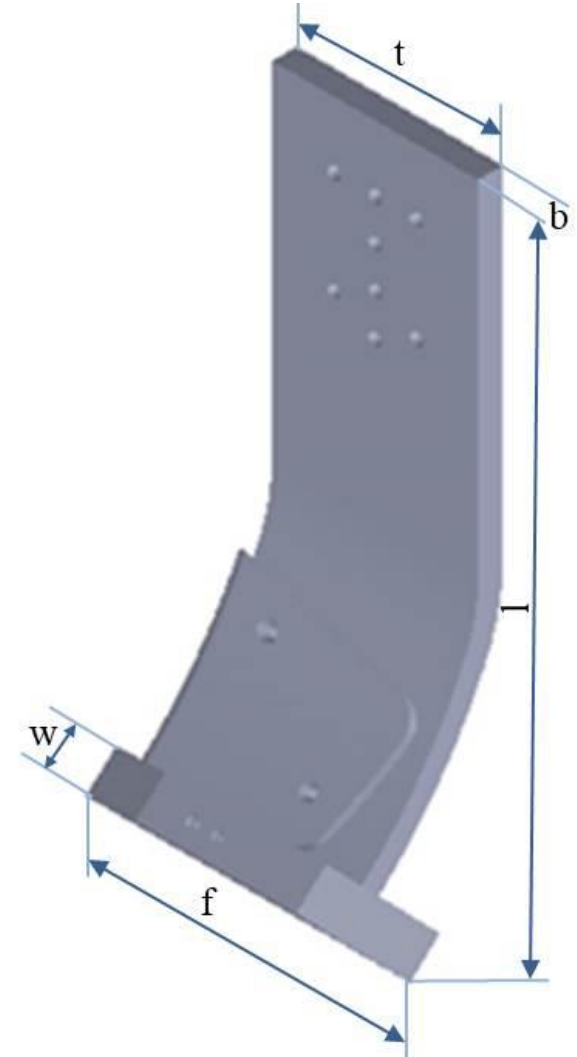

(b)

Figure 2 Subsoiler (a) and paraplow (b) dimensions
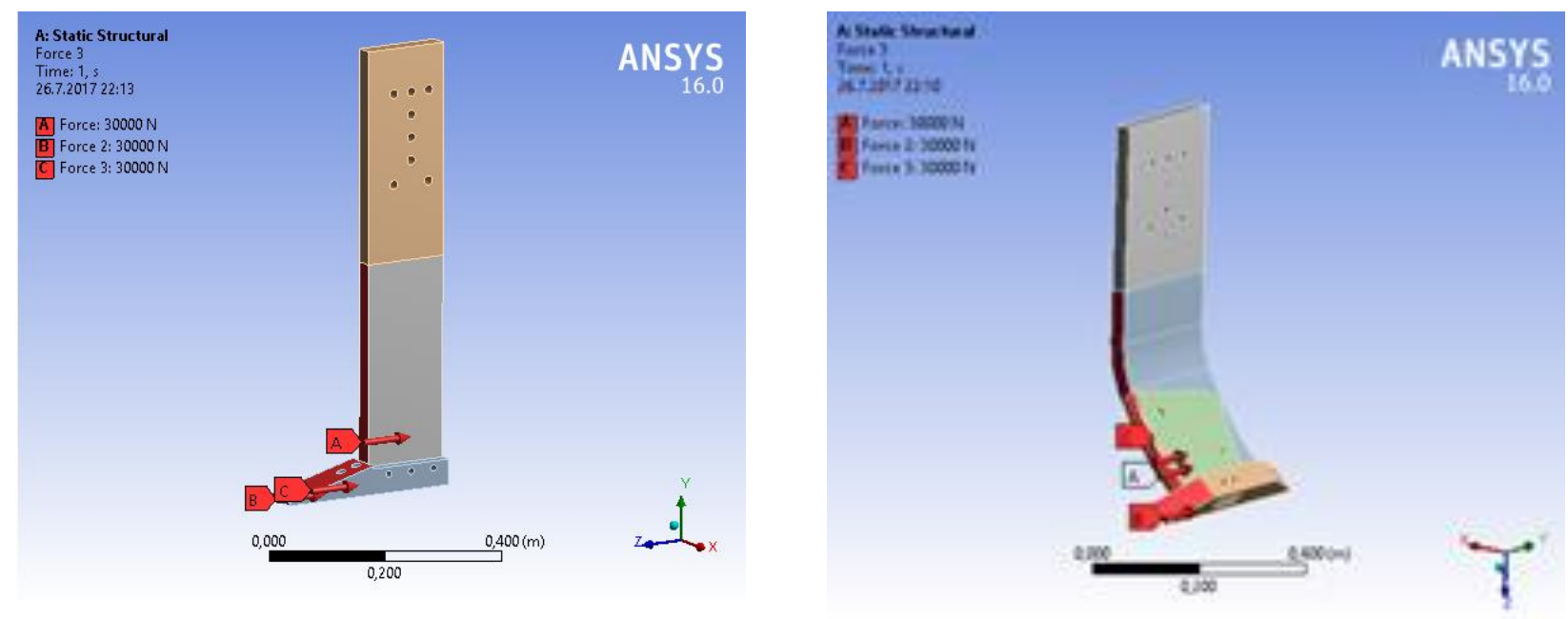

Figure 3 Boundary constraint of shanks 


\begin{tabular}{l|cc}
\hline \multicolumn{1}{c|}{ Properties } & \multicolumn{2}{c}{ Materials } \\
\cline { 2 - 3 } & St 52 & C60 stell \\
\hline Young's module $(\mathrm{GPa})$ & 205 & 193 \\
Poisson's ratio & 0.29 & 0.27 \\
Yield strength $(\mathrm{MPa})$ & 355 & 490 \\
Density $\left(\mathrm{kg} / \mathrm{m}^{3}\right)$ & 7870 & 7850 \\
Ultimate tensile strength $(\mathrm{MPa})$ & 520 & 875 \\
\hline
\end{tabular}
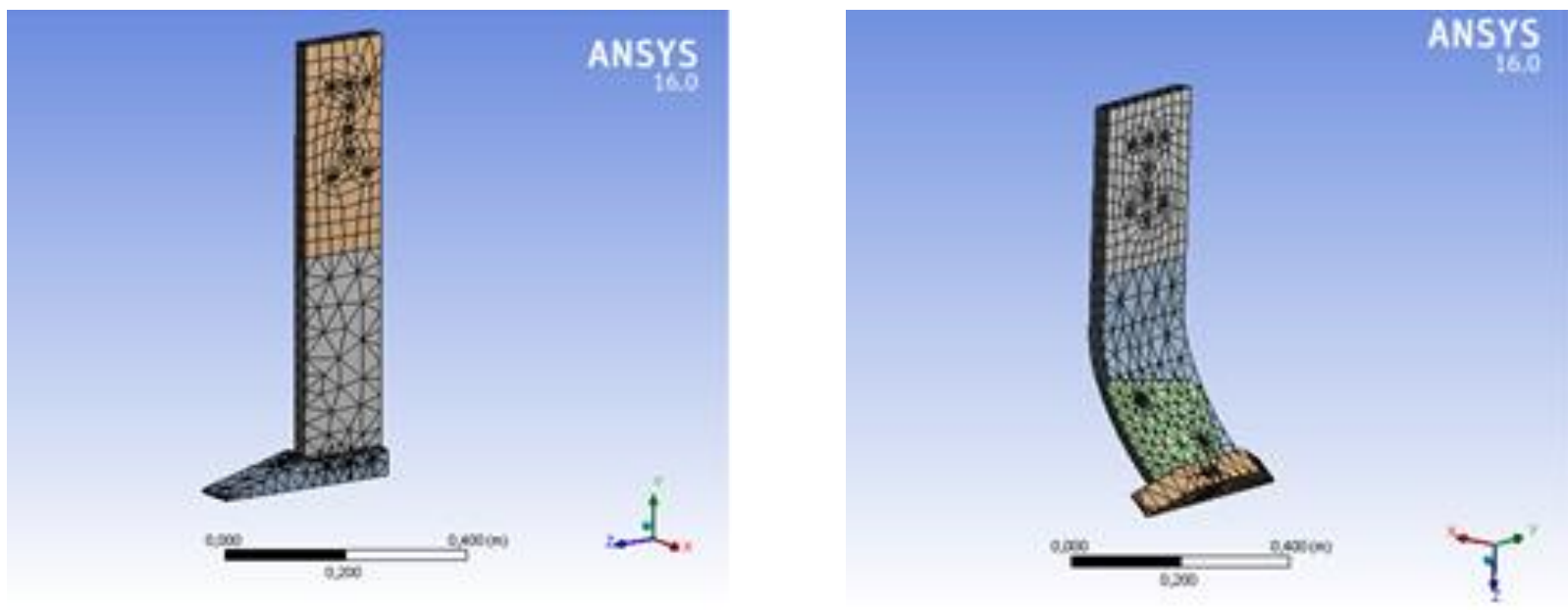

Figure 4 Meshing of shanks

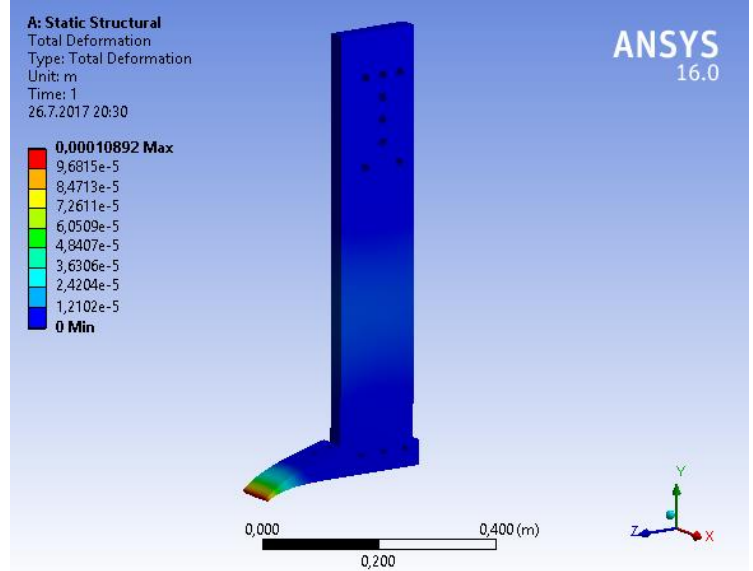

Total deformation of subsoiler shank (St-52)

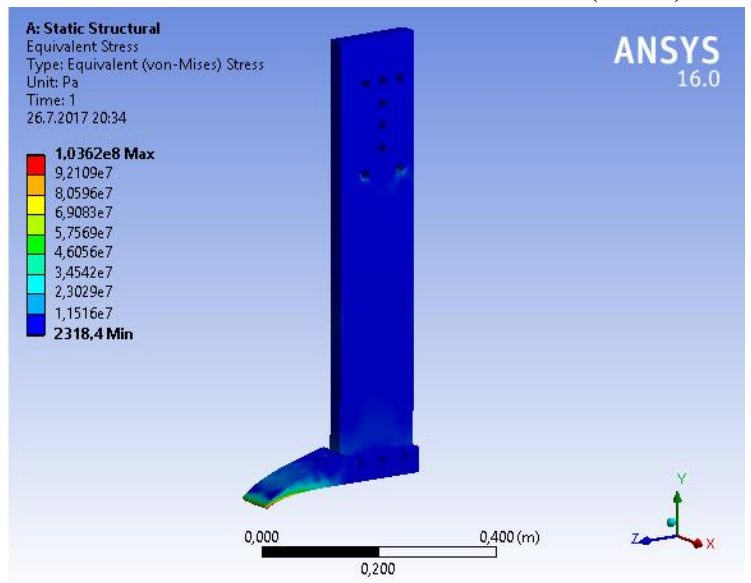

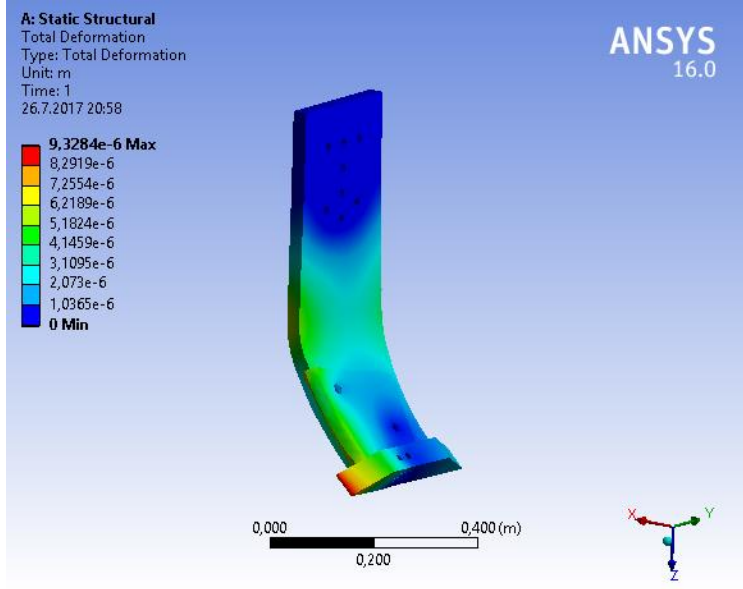

Total deformation of paraplow shank (St-52)

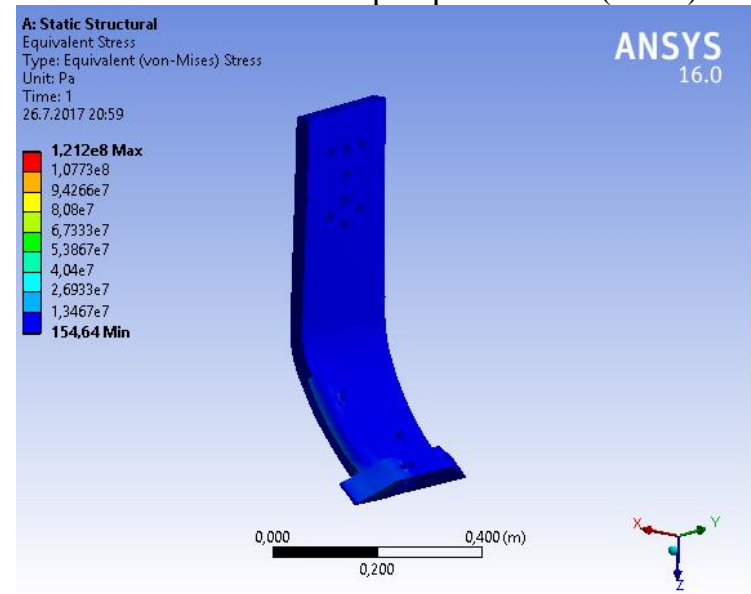

Equivalent (von-Mises) Stress of subsoiler shank (St-52) Equivalent (von-Mises) Stress of paraplow shank (St-52) Figure 5 Total deformation and Equivalent (von-Mises) Stress of subsoiler and paraplow shanks for St-52 


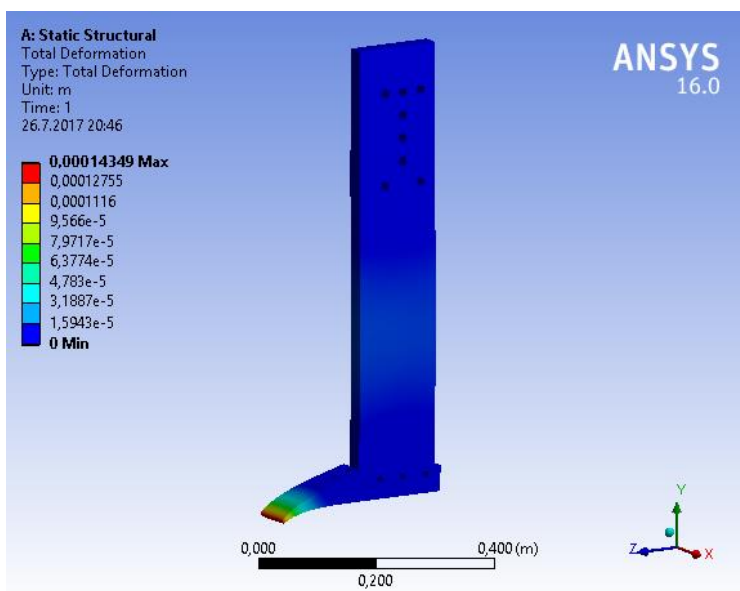

Total deformation of subsoiler shank (C 60)

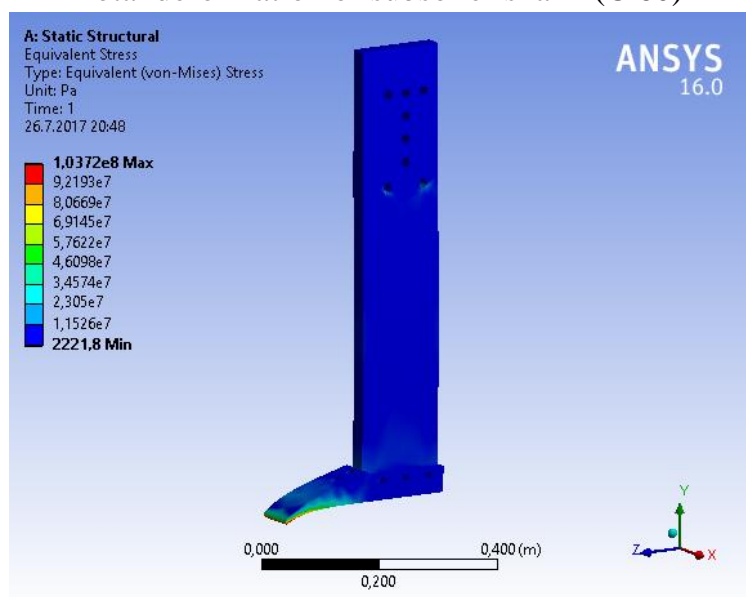

Equivalent (von-Mises) Stress of subsoiler shank (C 60)

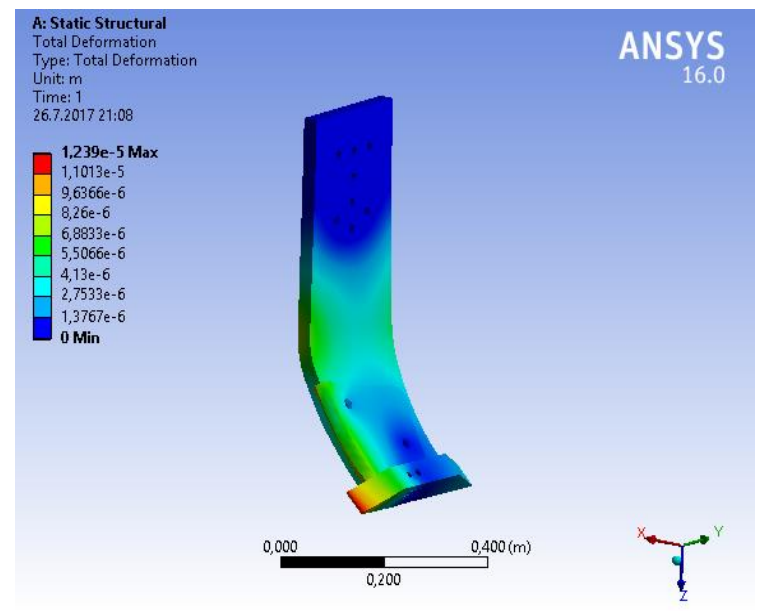

Total deformation of Paraplow shank (C 60)

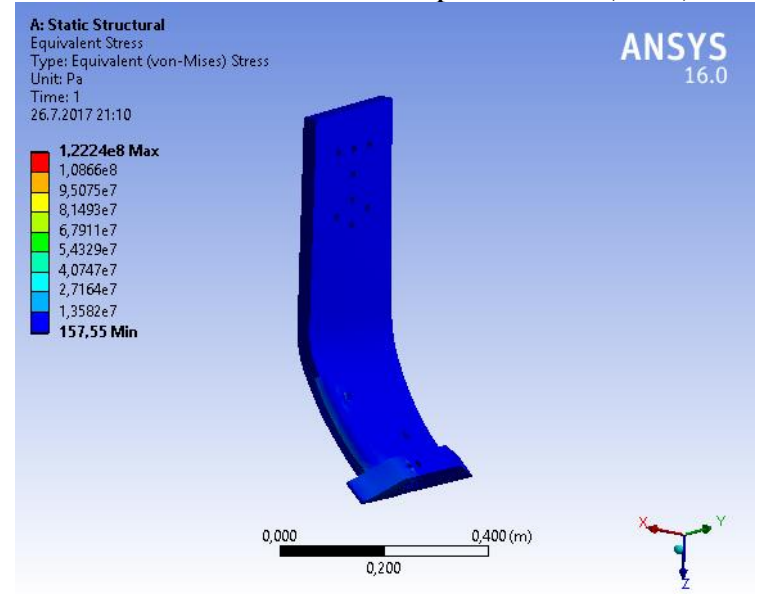

Equivalent (von-Mises) Stress of paraplow shank (C 60)

\section{Meshing}

Meshes which are achieved with high-automated networking environment used in the model are sparseness and non-uniformity. The numbers of the nodes and elements belonging to the subsoiler shank and paraplow shank were 9300 and 3751 respectively (Figure 4). Altough solving the fine mesh took longer time, the results were more accurate.

\section{Resistance Evaluation of Shanks}

After the setup of material definition, working conditions were set up in the FEM software taking into account of the actual values obtained by the Topakc1 at al. 2010 to simulate the act of the subsoiler and paraplow shanks under maximum draft force on tillage. The draft force $(30 \mathrm{kN})$ was applied in the opposite direction of forward direction. After running the FEM process in ANSYS 16 Work Bench, stress distributions were obtained on the construction of the shanks of subsoiler and paraplow. The stress solutions of shanks according to the different materials are given separately in Figures 5 and Figure 6.

In the solutions of the designs using St-52 material, the biggest total deformation occurred as $0,00010 \mathrm{~mm}$ in the subsoiler especially in front of the subsoiler foot. Based on evalution of maximum stress, it is seen that the greatest von mises value was realized as $121 \mathrm{MPa}$ in praplow foot. The yield strength of St-52 was $355 \mathrm{Mpa}$. The operating requirements of structural strength can be met and it had an enough safety coefficient. When c-60 material was examined in a similar way, It is seen that the total deformation was realized in the subsoiler foot with $0,00014 \mathrm{~mm}$. It is also seen that the von mises value for the C-60 material was $122 \mathrm{MPa}$, which is very close to the resolution for the same St-52 material.

\section{Results and Conclusion}

This study focused on the deformation and stress distribution of subsoiler and paraplow shanks design manufactured from two different materials by means of CAD and FEM applications.

A subsoiler and paraplow which had a single shank were used in the case study.

According to results of the analysis, maximum draft force of the tools was choosen as $30 \mathrm{kN}$ from the literature. The designs were drawn in the SolidWorks environment and the static analyzes were performed in the ANSYS 16.

According to result of the analysis, the maximum equivalent stress was in paraplow shank foot was 122 $\mathrm{MPa}$, which is used c-60 material and the maximum vertical dis-placement was $0,00014 \mathrm{~mm}$ in the position of shank foot of subsoiler. The equivalent stress values of 
the design of both tools were realized below the yield strength values (355 MPa for st-52 and $490 \mathrm{MPa}$ for c-60) of the selected materials.

In such a case, the material which is cheaper in the market for the construction of the tools may be selected for production purposes. In addition, an optimization study can be performed for future work. Thus, it is possible to work on saving the materials by lightening them.

\section{References}

Ahamadi I. 2016. Effect of soil, machine, and working state parameters on the required draft force of a subsoiler using a theoretical draft-calculating model. Soil Research 55(4) 389400.

Armin A, Fotouhi R, Szyszkowski W. 2014. On the FE modeling of soil-blade interaction in tillage operations. Finite Elements in Analysis and Design 92: 1-11.

Canillas EC, Salokhe VM. 2002. Modeling compaction in agricultural soils. Journal of Terramechanics 39: 71-84.

Çelik A, Raper RL. 2012. Design and evaluation of grounddriven rotary subsoilers. Soil and Tillage Research 124: 203-210.

Çelik A, Raper RL. 2016. Comparison of various coulter-type ground-driven rotary subsoilers in terms of energy consumption and soil disruption. Soil Use and Management. 32: $250-259$.

Ghosh PK, Mohanty M, Bandyopadhyay KK, Painuli DK, Misra AK. 2006. Growth, competition, yield advantage and economics in soybean/pigeonpea intercropping system in semi-arid tropics of India I. Effect of subsoiling. Field Crops Research 96:80-89
Hassan FU, Ahmad M, Ahmad N, Abbasi MK. 2007. Effects of subsoil compaction on yield and yield attributes of wheat in the sub-humid region of Pakistan. Soil \& Tillage Research 96: 361-366.

Ma Z, Yuan Y, Liu J, Yi Jinggang. 2016. Optimization design of subsoiling components. 2nd International conference on advances in mechanical engineering and industrial informatics (AMEII 2016). 399-402.

Nevens F, Reheul D. 2003. The consequences of wheel-induced soil compaction and subsoiling for silage maize on a sandy loam soil in Belgium. Soil \& Tillage Research 70: 175-184

Pınar Y, Selvi KÇ, Yılmaz S. 2008. Effect of soil compaction (plough pan) on soybean yield at Samsun conditions. Journal of Agricultural Machinery Science. 4(2): 165-170.

Raper RL. 2005. Force requirements and soil disruption of straight and bentleg subsoilers for conservation tillage systems. Appl. Eng. Agric. 21(5):787-794

Raper RL. 2007. In-Row subsoiler that reduce soil compaction and residue disturbance. Applied Engineering in Agriculture. 23:253-258.

Smith LA, Williford JR. 1988. Power requirements of conventional, triplex, and parabolic subsoilers. Transaction of the American Society of the Agricultural Engineers, 31: $1685-1688$.

Topakcı M, Çelik HK, Çanakcı M, Karayel D, Rennie A. 2010. Structural optimization of a subsoiler. Pakistan Journal of Scientific and Industrial Research. 53(5): 281-287.

Spoor G, Tijink FGJ, Weisskopf P. 2003. Subsoil compaction: risk, avoidance, identification and alleviation. Soil \& Tillage Research 73: 175-182. 